\title{
Food in a future of 10 billion
}

\author{
Nina V Fedoroff
}

\begin{abstract}
Over the past two centuries, the human population has grown sevenfold and the experts anticipate the addition of 2-3 billion more during the twenty-first century. In the present overview, I take a historical glance at how humans supported such extraordinary population growth first through the invention of agriculture and more recently through the rapid deployment of scientific and technological advances in agriculture. I then identify future challenges posed by continued population growth and climate warming on a finite planet. I end by discussing both how we can meet such challenges and what stands in the way.
\end{abstract}

Keywords: Population growth, Agriculture, Domestication, Genetic modification, Technology

\section{Background}

Today we have enough food to meet the world's needs. Indeed, we have an extraordinary global food system that brings food from all over the planet to consumers who can afford to buy it. The food price spike of 2008 and the resurgence of high food prices in recent years have had little impact on the affluent citizens of the developed world who spend a small fraction of their income on food. By contrast, food prices have a profound impact on the world's poorest people. Many of them spend half or more of their income on food. During the food price crisis of 2008, there were food riots in more than 30 countries. Unrest in the Middle East and North Africa tracks with the price of food, as is dramatically illustrated in Fig. 1. Spiraling food prices drive the world's poorest into chronic hunger even in a world of relative plenty.

Does this mean we need worry only about poverty, not about the global food supply, as suggested in a recent editorial by the influential New York Times food commentator Mark Bittman [2]? Analyses of the most recent United Nations projections indicate that the human population will expand from roughly 7.2 billion today to 9.6 billion in 2050 and 10.9 billion by 2100 [3, 4]. Current yield growth trends are simply insufficient to keep up with growing demand [5]. As well, the rapid expansion of agriculture

*Correspondence: nvf1@psu.edu

Evan Pugh Professor Emerita, Penn State University, University Park, PA 16802, USA over the past century to feed today's population has had a devastating impact on biodiversity [6]. As a result, there is an acute need to intensify agricultural productivity, while at the same time decreasing the deleterious impact of agriculture on biodiversity and the services provided by complex ecosystems [7].

\section{Historical perspective}

For most of our evolutionary history, our numbers were small and we were mobile hunter-gatherers. We spent our time finding and capturing enough food to feed ourselves and our closest kin. Then sometime between 10 and 20,000 years ago-maybe even more-that started to change. We began to shape plants and animals to our own advantage and settled down to grow and herd them [8]. The process by which we have modified plants and animals to suit our needs, traditionally called "domestication," is a process of genetic modification [9]. Early peoples selected variant organisms-plants, animals, and microbes-with useful traits, such as seeds that adhere to plants until they are harvested and animals tame enough to herd. Domestication is a process of modification that is possible because of the genetic variation constantly arising in all living organisms.

While hunter-gatherers were quite sophisticated in their resource management, it was systematic planting and harvesting of crops that marks the origin of what we now call "agriculture" [10]. Agriculture allowed people to produce more food than they consumed; cities and civilization followed. Thus human civilization 


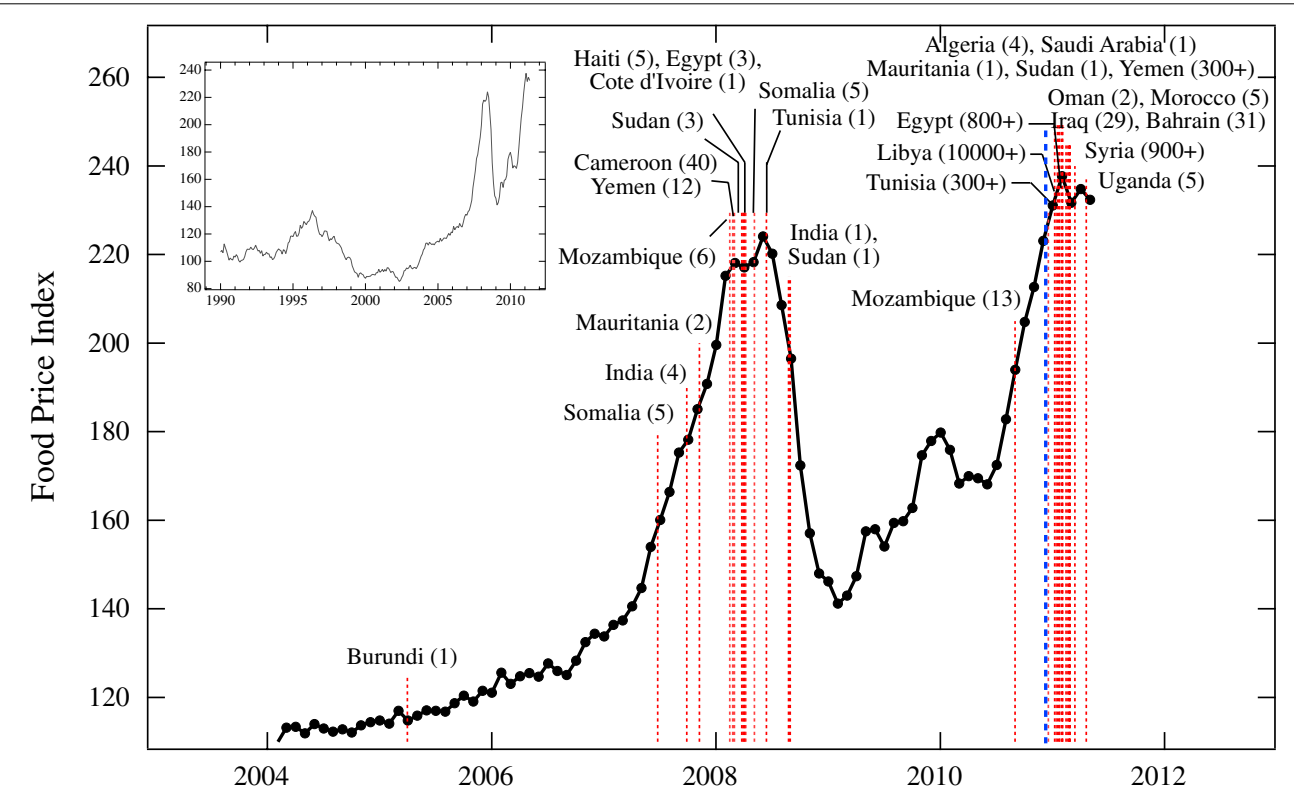

Fig. 1 Food price spikes are correlated with increases in food riots. Red dashed vertical lines correspond to beginning dates of "food riots" and protests associated with the major recent unrest in North Africa and the Middle East. The overall death toll is reported in parentheses. The blue vertical line indicates the date on which the authors of the cited report [1] submitted a report to the U.S. government warning of the link between food prices, social unrest, and political instability. The inset shows the FAO Food Price Index from 1990 to 2011. (The figure is reproduced with permission from [1]).

emerged because we figured out how to produce surplus food. We could feed artisans and scribes and warriors and kings. For the next 10 millennia, people built cities and civilizations, wore out the land, invaded their neighbors or abandoned the cities and civilizations, eventually rebuilding on fresh land [11]. It was often the fertility of the land that determined how long a civilization lasted. Plants extract nutrients from the soil and crop yields decline, making it harder and harder to produce enough food as the number of people grows [8].

Concern about access to sufficient food, today called "food security," is as old as mankind. Thomas Malthus' famous Essay on Population, published in 1798, crystallized the problem of balancing food and human population for the modern era [12]. Malthus believed that humanity was doomed to food insecurity because our numbers increased exponentially, while our ability to produce food could only increase linearly.

Curiously, Malthus penned his essay at about the time that science began to play a major role in boosting agricultural productivity. Late eighteenth century milestones were Joseph Priestley's discovery that plants emit oxygen and Nicholas-Théodore de Saussure's definition of the chemical composition of plants [13, 14]. Malthus could not have envisioned the extraordinary increases in productivity that the integration of science and technology into agricultural practice would stimulate over the ensuing two centuries.

Both organic- and mineral fertilization of plants have been practiced since ancient times. Farmers knew that certain chemicals and biological materials, ranging from fish and oyster shells to manure and bones, stimulated plant growth $[15,16]$. Justus von Liebig made important contributions to the study of plant nutrient requirements, understanding that biological sources of nitrogen could be replaced with purely chemical sources. But supplying nitrogen in the forms that plants use remained a major limitation until the development of the Haber-Bosch process for fixing atmospheric nitrogen early in the twentieth century [17]. Today, agriculture in the developed world relies primarily on chemical fertilizers. Indeed, the global human population could not have grown from roughly 1 billion at the turn of the nineteenth century to today's 7.2 billion without synthetic nitrogen fertilizer.

\section{Crop domestication}

Humans practiced genetic modification long before chemistry entered agriculture, transforming inedible wild plants into crop plants, wild animals into domestic animals, and harnessing microbes to produce everything from cheese to wine and beer. Oddly, it is only our contemporary methods of bending organisms' genetic constitution to suit our needs that are today recognized 
as genetic modification, known in common parlance by the abbreviations "GM" (genetically modified), "GMO" (genetically modified organism) or "GE" (genetically engineered). Yet all of the useful, heritable traits nurtured by people in organisms constitute "domestication" and all are the result of genetic modifications. Each microbe, crop and animal has its own interesting history. To take just one example, a fundamental trait that distinguishes wild from domesticated plants is the retention of mature seeds on the plant. Plants have many mechanisms for dispersing their seeds, but it is much easier for people to harvest seeds that remain attached to the plant at maturity. Hence one of the earliest steps in grain crop domestication was the identification of mutationsgenetic changes-that prevent seed dispersal [18].

Corn, also known as maize, remains one of our most spectacular feats of genetic modification. Its huge ears, packed with starch and oil, provide one of humanity's most important sources of food and feed. Corn bears little resemblance to its closest wild relative, teosinte. Indeed, when teosinte was first discovered in 1896, it was assigned to a different species [19]. By the 1920s, it was known that teosinte and corn readily produce fertile hybrids, but controversies about their relationship and about the origin of corn continued throughout most of the twentieth century. The key genetic changes that transformed teosinte into corn appear to have happened in the Balsas River Valley in Mexico some 9000 years ago [20]. The mutations that converted teosinte, a grass with hard, inedible seeds, into modern corn altered just a handful of genes that control plant architecture and the identity of reproductive organs. Remarkably, once these mutations had been brought together in an early corn plant, they stayed together and spread very rapidly, moving from Mexico into the American southwest by 3000 years ago [20].

Among the many other traits altered during domestication of plants are the size and shape of leaves, tubers, berries, fruits and grains, as well as their abundance, toxicity, and nutritional value. The changes are often in genes coding for proteins that regulate the expression of many other genes [9]. Differences in nutrient composition among varieties of the same crop are caused by mutations in genes coding for proteins in a number of different biosynthetic pathways. Thus, for example, sweet corn has mutations that prevent the conversion of sugar to starch in the kernel [21].

\section{Modern crop improvement}

The genetic revolutions of the twentieth century boosted crop productivity immeasurably. Austrian monk Gregor Mendel's pioneering observations on inheritance were published in 1865, but did not get wide attention until a half-century later [22]. A simple demonstration project to illustrate Mendelian inheritance led to the re-discovery of hybrid vigor, a long-known phenomenon whose incorporation into crop breeding resulted in a dramatic expansion of the corn ear and, thereby, crop yield [23].

However, when corn hybrids were first introduced in the U.S. during the 1930s, they faced resistance and criticism similar to that leveled at contemporary GM crops. The hybrids were complex to produce and agriculture experiment stations were not interested. Eventually a company was formed to produce hybrid seed. But farmers accustomed to planting seed from last year's crop saw no reason to buy it. It was only when farmers realized the yield benefits and the drought-resistance of hybrid corn during the 1934-1936 dust-bowl years that farmers began to adopt hybrid corn rapidly [24].

Techniques for accelerating mutation rates with radiation and chemicals and through tissue culture were developed and widely applied in the genetic improvement of crops during the twentieth century [25]. These methods introduce mutations rather indiscriminately and require the growth of large numbers of seeds, cuttings or regenerants to detect desirable changes. Nonetheless, all of these approaches have proved valuable in crop improvement and by the end of the twentieth century, more than 2300 different crop varieties, ranging from wheat to grapefruit, had been developed using radiation and chemical mutagenesis [25].

\section{Mechanization of agriculture}

A major development with impact Malthus could not have envisioned is the mechanization of agriculture. Human and animal labor provided the motive force for agriculture throughout most of its history and continues to do so in many less-developed countries. The invention of the internal combustion engine at the turn of the twentieth century led to the development of small, maneuverable tractors. The mechanization of plowing, seed planting, cultivation, fertilizer and pesticide distribution, and harvesting accelerated in the US, Europe, and Asia following World War II [26]. Agricultural mechanization drove major demographic changes virtually everywhere. In the U.S., $21 \%$ of the workforce was employed in agriculture in 1900 [27]. By 1945, the fraction had declined to $16 \%$ and by the end of the century the fraction of the population employed in agriculture had fallen to $1.9 \%$. At the same time, the average size of farms increased and farms increasingly specialized in fewer crops. This profound demographic shift from agrarian to urban underlies the development of today's attitudes about food and farming in developed countries. Today the vast majority of the developed world's population is urban and far removed from primary food production. 


\section{The Green Revolution}

Malthus penned his essay when the human population of the world stood at less than a billion. The population tripled over the next century and a half. As the second half of the twentieth century began, there were neo-Malthusian predictions of mass famines in developing countries that had not yet experienced science- and technologybased advances in agriculture. Perhaps the best known of the mid-century catastrophists was Paul Ehrlich, author of The Population Bomb [28].

Remarkably, the extraordinary work of just a handful of scientists and their teams, principally plant breeders Norman Borlaug and Gurdev Khush, averted the widely predicted Asian famines [29]. The Green Revolution was based on the development of dwarf rice and wheat varieties that responded to fertilizer application without falling over (lodging). Subsequent breeding for increased yield continued to improve the productivity of these crops by as much as $1 \%$ per year. Perhaps most remarkably, the Green Revolution and other technological advances reduced the fraction of the world's hungry from half to less than a sixth, even as the population doubled from 3 to 6 billion. These accomplishments earned Borlaug a well-deserved Nobel Prize. Curiously, the Green Revolution is often vilified today.

\section{Genetic modification of crops}

The equally revolutionary molecular genetic advances that began in the 1960s led to the development of new methods of crop improvement. The basic methodology lies in the construction of hybrid DNA molecules designated "recombinant DNA (R-DNA)" because they consist of a piece of bacterial or viral DNA combined with a piece of DNA from a different kind of organism, plant or animal [30]. The ability to multiply such hybrid DNA molecules in bacteria made it possible to develop the DNA sequencing techniques that underlie today's genomic revolution.

As well, techniques were developed to introduce genes into plants using either the soil bacterium Agrobacterium tumefaciens, which naturally transfers a segment of DNA into a plant cell, or mechanical penetration of plant cells using tiny DNA-coated particles [31]. This combination of methods and knowledge made it possible to transfer a well-understood segment of genetic material from either the same or a related plant or from a completely unrelated organism into virtually any crop plant, creating what is known as a "transgenic" plant. Because genes work the same way in all organisms, this made it possible to introduce a desirable trait, such as disease- or pest-resistance, without the extensive genetic and epigenetic disturbance attending what we now consider to be the "conventional" crop improvement techniques such as hybridization and mutagenesis [32-34]. Indeed, recent comparisons have revealed plant modification by molecular techniques has less impact on gene expression, protein, and metabolite levels than do conventional genetic crosses [35-37].

Several crop modifications achieved using these methods are now in widespread use. Perhaps the best known of these are crop plants containing a gene from the soil bacterium, Bacillus thuringiensis, long used as a biological pesticide. The gene encodes a protein that is toxic to the larvae of certain kinds of insects, but not to animals or humans [38]. Such a toxin gene is often called the "Bt gene," but is actually a family of related toxin genes from a group of closely related bacteria and these are increasingly used in combinations to decrease the probability of resistance developing in the target insects, an approach that has been dubbed gene "stacking."

Herbicide tolerance is another widely accepted GM crop modification. Among the most common herbicides in use today are compounds that interfere with the production of certain amino acids that plants synthesize, but animals do not [39]. Such herbicides, therefore, kill plants, but have low or no toxicity for animals or humans. Herbicide-tolerant crops make it possible to control weeds without damaging the crop and without tilling the soil. Such crops have been derived through natural mutations and induced mutations, as well as by introduction of genes from either bacterial sources or plant sources. Today, herbicide-tolerant varieties of many crops, most importantly soybeans and canola, are widely grown [40].

Papayas resistant to papaya ringspot virus (PRSV) saved the Hawaiian papaya industry and are the only such GM crop to emerge from public sector GM research. Papaya ringspot virus is a devastating insectborne viral disease that wiped out the papaya industry on the Hawaiian island of Oahu in the 1950s, forcing its relocation to the Puna district of the big island. PRSV was first detected in the Puna district in 1992; by 1994 it was widespread and threatening the industry. A project initiated in 1987 introduced a gene from the PRSV into papayas based on reports that introducing a viral gene could make a plant resistant to the virus from which the gene came [41, 42]. Transgenic seeds were released in 1998; by 2000 , the papaya industry was returning to pre- 1995 levels. This remarkable achievement of disease resistance enhanced a virus protection mechanism already present in the plant, much as vaccination protects people and animals from infection by pathogens [43].

New methods are rapidly being developed that promise to further increase the specificity and precision of genetic modification. These techniques capitalize on growing knowledge of the dynamic processes underlying genome maintenance, particularly the repair of 
breaks in the genetic material, DNA. Known under the general rubric of "site-directed nuclease (SDN)" technology, this approach uses proteins (or protein-nucleic acid complexes) that seek out, bind to, and cut specific DNA sequences, introducing breaks in the DNA at one or a small set of sequences targeted for modification [44]. Repair of such DNA cuts by natural cellular processes results in precisely targeted genetic changes rather than the random ones introduced by older methods of mutagenesis. This method can also be used to introduce a gene at a pre-identified site in the genome or to modify a resident gene precisely, something that could not be done with pinpoint specificity and precision by R-DNA methods. As well, such genetic changes can often be made without creating a transgenic plant. The changes are the same at the molecular level as those that occur in nature or can be induced by older mutagenic techniques. What is new is that the genetic changes introduced by SDN techniques are not random, but confined precisely to the gene or genes selected by the breeder.

\section{Adoption of GM crops}

GM crops have been adopted at unprecedented rates since their commercial introduction in 1996. In 2014, GM crops were grown in 28 countries on 181.5 million hectares [45]. More importantly, more than $90 \%$ of the 18 million farmers growing biotech crops today are smallholder, resource-poor farmers. The simple reasons that farmers migrate to GM crops are that their yields increase and their costs decrease. A recent meta-analysis of 147 crop studies conducted over a period of 20 years concluded that the use of GM crops had reduced pesticide use by $37 \%$, increased crop yields by $22 \%$, and increase farmers' profits by $68 \%$ [46]. The vast majority of GM hectarage is devoted to the growing of GM corn, soybeans, cotton, and canola with either Bt toxin-based pest resistance or herbicide tolerance traits. The reasons for the narrow GM crop and trait base to date lie in a combination of the economic, regulatory, and legal issues, discussed below.

While some resistance to the Bt toxin has developed, it has not been as rapid as initially feared and second-generation, two-Bt gene strategies to decrease the probability of resistance are already being implemented [47]. Predicted deleterious effects on non-target organisms, such as monarch butterflies and soil microorganisms have either not been detected at all or are insignificant [48]. The better cropping practices supported by GM crops have decreased the availability of the milkweed on which monarch larvae feed [49]; hence efforts are being directed to the establishment of milkweed preserves (http:// monarchjointventure.org/get-involved/create-habitatfor-monarchs/). The development of herbicide tolerance in previously susceptible weeds, while not unique to GM crops, is becoming an increasing problem because of the widespread use of glyphosate with glyphosate-tolerant GM crops [50]. Although the pace of herbicide discovery has slowed markedly since the 1980 s, new combinations of herbicide-tolerant crops and older herbicides are likely to come on the market in the near future [51].

The overwhelming evidence is that the GM foods now on the market are as safe, or safer, than non-GM foods $[37,52]$. Moreover, there is no evidence that the use of GM techniques to modify organisms is associated with unique hazards. The European Union alone has invested more than $€ 300$ million in GMO biosafety research. Quoting from its recent report, "The main conclusion to be drawn from the efforts of more than 130 research projects, covering a period of more than 25 years of research and involving more than 500 independent research groups, is that biotechnology, and in particular GMOs, are not per se more risky than, e.g. conventional plant breeding technologies." (http://ec.europa.eu/research/ biosociety/pdf/a_decade_of_eu-funded_gmo_research. pdf). Every credible scientific body that has examined the evidence has come to the same conclusion (http:// gmopundit.blogspot.com/p/450-published-safety-assessments.html).

Despite occasional one-of-a-kind, often sensationalized reports, the vast majority of feeding studies have identified no meaningful nutritional differences between GM and non-GM food and feed. Indeed, and perhaps unsurprisingly, comparative molecular analyses show that GM techniques have less impact on the genetic and molecular constitution of crop plants than conventional plant breeding techniques [37]. This is because conventional breeding mixes whole genomes comprising tens of thousands of genes that have previously existed in isolation, while GM methods generally add just a gene or two to an otherwise compatible genome. Thus the probability of introducing unexpected genetic or epigenetic changes is much smaller by GM methods than by conventional breeding methods.

Crops modified by GM techniques are also less likely to have unexpected genetic effects than crops modified by the more conventional techniques of chemical and radiation mutagenesis methods simply because of the greater precision and predictability of molecular modification. Taken together with the closer scrutiny paid during product development to the potential for toxicity and allergenicity of novel proteins expressed by GM methods, GM crops are arguably the safest new crops ever introduced into the human and animal food chains.

Indeed, to date, the only unexpected effects of GM crops have been beneficial. Many grains and nuts, including corn, are commonly contaminated by mycotoxins, 
which are toxic and carcinogenic compounds made by fungi that follow boring insects into the plants. Bt corn, however, shows as much as a $90 \%$ reduction in mycotoxin levels because the fungi that follow the boring insects into the plants cannot get into the Bt plants [53]. There is also evidence that planting Bt crops reduces insect pressure in non-GM crops growing nearby. The widespread adoption of Bt corn in the U.S. Midwest has resulted in an area-wide suppression of the European corn borer [54].

\section{Future challenges in agriculture}

Since Malthus' time, the human population has expanded more than sixfold. Through science and technology, agriculture in developed nations has become far less laborintensive and has kept pace with population growth worldwide. Today, fewer than 1 in 50 citizens of developed countries grows crops or raises animals for food. But after a half-century's progress in decreasing the fraction of humanity experiencing chronic hunger, the food price and financial crises commencing in 2008 have begun to swell the ranks of the hungry once more $[1,55]$. Population experts anticipate the addition of another 2-4 billion people to the planet's population within the next $3-4$ decades $[4,56,57]$, but the amount of arable land has not changed appreciably in more than half a century [58]. Moreover, arable land continues to be lost to urbanization, salinization, and desertification.

Supplies of fresh water for agriculture are under pressure, as well. Today, about a third of the global population lives in arid and semi-arid areas, which cover roughly $40 \%$ of the land area. Climate scientists predict that in coming decades, average temperatures will increase and dryland area will expand. Inhabitants of arid and semiarid regions of all continents are extracting ground water faster than aquifers can recharge and often from fossil aquifers that do not recharge [59]. Yet the major crops that now feed the world-corn, wheat, rice, soy-require a substantial amount of water. It takes $500-2,000 \mathrm{~L}$ of water to produce a kilogram of wheat and the amount of water required to produce a kilogram of animal protein is 2-10 times greater [60].

Increasing average temperatures and decreasing fresh water availability present critical challenges to agricultural researchers to increase crop performance under suboptimal conditions. Rapid advances in our knowledge of plant stress responses and improving molecular knowledge and tools for plant breeding have already resulted in the introduction of new drought-tolerant crop varieties, both GM and non-GM [61]. New varieties of drought-tolerant maize produced using modern breeding approaches that employ molecular markers, but do not generate transgenic plants, have been released in the North American market by Syngenta and DuPont Pioneer, while Monsanto and BASF have jointly developed MON87460 (aka Genuity DroughtGard Hybrids), a drought-tolerant maize variety expressing a cold-shock protein from the bacterium Bacillus subtilis, introducing it in the U.S in 2013 (http://www.monsanto.com/products/pages/droughtgard-hybrids.aspx).

However, it should be kept in mind that suboptimal "stress" conditions necessarily move plants away from their peak ability to use sunlight to convert carbon dioxide, water, and other simple compounds into the carbohydrates and proteins that feed people and animals. Stress-tolerant varieties do not generally outperform less stress-tolerant varieties by much or at all under optimal conditions, but simply survive better under suboptimal conditions, losing less of their yield potential.

\section{More with less}

Why do we need to do more with less? The FAO has estimated that we will need to increase the amount of food produced by $70 \%$ by 2050 [62]. We will need more food, feed, and fiber both because there will be more people and because they will be richer. Among the things that people demand as they become more affluent is more meat in their diet. Producing more meat requires growing more grain. But increasing the grain supply by expanding the land under cultivation cannot be sustained. All the best land is already under cultivation and preserving what remains of our planet's rich biological heritage by leaving more land unplowed is a growing priority. Indeed, modeling exercises reveal that within just a few decades, the planet's natural resources will be insufficient to support developed-world consumption patterns [63].

As well, the negative impact of climate change on agriculture is becoming increasingly apparent and is predicted to worsen [64,65]. While more agriculturally suitable land may become available at greater distances from the equator as the climate warms, there is no guarantee that the productivity of these lands will compensate for productivity losses in the more populous equatorial regions. Whether our current highly productive food and feed crops can be modified and adapted to be substantially more productive at the higher temperatures expected or at more northern latitudes with shorter growing seasons is not yet known. Substantial research will be required not just on the salt, drought, and temperature tolerance of existing crop plants, but also for the domestication of plants that are not now used in agriculture, but that are capable of growing at higher temperatures and on saline water.

In today's highly productive developed-world agriculture, fertilizers and other chemicals are applied and 
used inefficiently, themselves becoming pollutants in our air, land, and water. As well, some of the chemicals used in both conventional and organic agriculture to control pests and diseases are toxic to people and to wildlife. Transitioning to more sustainable agricultural practices while doubling the food and feed supply, even as we must increasingly cope with the negative effects on agricultural productivity of a warming climate, is likely to be the greatest challenge of the twenty-first century $[66,67]$.

\section{Impediments to sustainable intensification of agriculture}

To live sustainably within planetary constraints, we must grow more on the same amount of land using less water, energy, and chemicals. The molecular genetic revolution of the late twentieth century that powered the development of precise GM methods is the most critical technology for meeting these challenges. Paradoxically, although the use of GM technology has been accepted in medicine, it has evoked an almost unprecedented level of societal controversy in the realm of food production, resulting in the proliferation of regulatory and legal constraints that threaten to cripple their use in achieving a more sustainable existence for humanity on planet Earth.

While productivity gains based on earlier scientific advances can still increase food production in many countries, particularly in Africa, such productivity gains appear to have peaked in most developed countries and recent productivity gains have been achieved largely through adoption of GM crops [68]. The knowledge and GM technology are available to address these challenges throughout the world, but there are political, cultural, and economic barriers to their widespread use in crop improvement. As noted earlier, there is a global consensus among scientific societies that GM technology is safe. However, the political systems of Japan and most European and African countries remain opposed to growing GM crops. Many countries lack GM regulatory systems or have regulations that prohibit growing and, in some countries, importing GM food and feed.

Even in countries such as the U.S. that have a GM regulatory framework [69], the process is complex, slow, and expensive. U.S. developers must often obtain the approval of three different agencies, the Environmental Protection Agency, the U.S. Department of Agriculture (USDA), and the Food and Drug Administration, to introduce a new GM crop into the food supply. Bringing a GM crop to market, including complying with the regulatory requirements, was estimated to cost $\$ 135$ million in 2011 [70]. The effort, time, and cost for regulatory approval have dramatically contracted the pipeline of GM innovations that would directly benefit consumers [71].
In Europe, the regulatory framework is practically nonfunctional; only one GM crop is currently being grown and only two others have gained approval since 1990 when the EU first adopted a regulatory system [72]. The EU recently agreed to allow member countries decide individually whether to permit cultivation of an EUapproved GM crop (http://ec.europa.eu/food/plant/gmo/ legislation/future_rules_en.htm). The impact of this decision will not be known for some time, but it is likely to further complicate trade and food aid as crops approved in one country await regulatory approval in others [73]. Moreover, the increasing politicization of risk assessment makes it unlikely that uniform global safety standards for GM crops and animals will emerge in the foreseeable future [74]. European influence has been especially detrimental in Africa, causing African leaders to be excessively precautionary in approving GM crops and even to ban the import of GM grain to alleviate famine [75].

However, it is the case of Golden Rice, genetically modified to produce the vitamin A precursor $\beta$-carotene, that provides the paradigmatic example of an opportunity foregone to use GM technology to address a major global malnutrition issue [76]. Severe vitamin A deficiency results in blindness, and half of the roughly half-million children who are blinded by it annually die within a year. Vitamin A deficiency also compromises immune system function, exacerbating many kinds of illnesses. It is a disease of poverty and poor diet, responsible for 1.9-2.8 million preventable deaths annually, mostly of children aged less than 5 years and women $[77,78]$.

Two scientists, Ingo Potrykus and Peter Beyer, and their teams developed a rice variety whose grains accumulate $\beta$-carotene, which our bodies convert to vitamin A. Collaborating with the International Rice Research Institute over a period of a quarter century, they developed and tested a transgenic rice variety that expresses sufficient quantities of $\beta$-carotene so that a few ounces of cooked rice can provide enough to eliminate the morbidity and mortality of vitamin A deficiency [79]. Yet, Golden Rice remains mired in controversy and has been tied up in the regulatory process for more than a decade [80]. Millions suffer and die while Golden Rice remains in test plots.

The increasing politicization of risk determination raises questions about the underlying motivations [74]. NGOs, most vocally Greenpeace and Friends of the Earth, appear to have conducted vigorous campaigns of misinformation about GMOs first in Europe, then around the world [81-85]. Greenpeace remains adamantly against even the most benign and beneficial uses of GM technology in agriculture, such as the development and distribution of Golden Rice. Given the weight of scientific evidence to the contrary, it is difficult to 
avoid the conjecture that its continued opposition to a harmless and beneficial technology has more to do with preserving its funding base than benefitting humanity $[84,85]$.

Perhaps the most counterproductive development is the increasing vilification of GM foods as a marketing tool by the organic food industry [86]. The organic food industry finds it roots in rural India, where Sir Albert Howard, arguably the father of "organic" agriculture, developed composting methods capable of killing the pathogens that abound in animal manures and human wastes so that these could be used safely as fertilizers in agriculture [30]. Even as synthetic fertilizers were increasingly being used around the world, the organic movement grew in the UK and Europe, eventually finding an American champion in Jerome Rodale, founder of the Rodale Press, and pesticide crusader Rachel Carson, author of Silent Spring, the book that has been credited with starting the environmental movement [87].

With the establishment of organic retailers, such as Whole Foods and Wild Oats, the organic food business grew rapidly and certification organizations proliferated. To bring some uniformity to what was being certified as "organic," Congress established the National Organic Standards Board (NOSB) under the USDA through the Organic Food Production Act and charged it with developing national standards [30]. These were eventually published in 2000 and are generally referred to as the Organic Rule. According to the NOSB, organic agriculture is a production system that makes minimal use of off-farm inputs and seeks to enhance "ecological harmony." The Organic Rule expressly forbids the use of GM crops, antibiotics, and synthetic nitrogen fertilizers in crop production and animal husbandry, as well as food additives and ionizing radiation in food processing.

Organic food is food produced in compliance with the Organic Rule; the USDA's Organic Seal is a marketing tool that makes no claims about food safety or nutritional quality. But a number of organic food industry marketers have systematically used false and misleading claims about the health benefits and relative safety of organic foods compared with what are now called "conventionally grown" foods [86]. Indeed, such organic marketers represent conventionally grown foods as swimming in pesticide residues, GM foods as dangerous, and the biotechnology companies that produce GM seeds as evil, while portraying organically grown foods as both safer and more healthful. Recent "labeling" campaigns have the objective of promoting the organic food industry by conveying the message to consumers that food containing GM ingredients is dangerous [86].

\section{The future}

In 1798, Thomas Malthus told us that humanity was doomed to famine and strife because population growth would always outstrip our ability to produce food [12]. The human population of the Earth then numbered about a billion. The ensuing two centuries have seen a more than sevenfold expansion of the human population as a result of rapid scientific and technical developments in agriculture and a decline in the number of chronically hungry from half of humanity to about a sixth. But as Nobel Laureate Norm Borlaug, Father of the Green Revolution, observed in his Nobel Prize lecture (http:// www.nobelprize.org/nobel_prizes/peace/laureates/1970/ borlaug-acceptance.html), "We may be at high tide now, but ebb tide could soon set in if we become complacent and relax our efforts." Said another way, agriculture must ever race to maintain today's status quo.

And yet agriculture is now threatened in a sense by its very success. The demographic shift of population from rural to urban areas has been particularly dramatic in the developed world, with less than $2 \%$ of the population supplying the food for the rest today. But the very fact that we are largely urban dwellers and have access to food through a global food system that supplies our food retailers with abundant produce blinds us to the basics of agriculture and makes us vulnerable to the increasingly strident opponents of modern agriculture who use fear to promote their economic interests.

Will we have the wisdom to overcome our fear of new technologies and re-invest in the kind of agricultural research and development that can simultaneously increase agricultural productivity and decrease its environmental impact, so that we might preserve what remains of our extraordinary biological heritage? Can we continue to keep food prices down through agricultural innovation based on modern genetic methods and better farm management? Or will poverty-based social instability continue to spread and consume governments as population continues to climb while climate warming squeezes agriculture?

The answers to these questions will, for better or worse, shape our future civilizations.

\section{Abbreviations}

DNA: deoxyribonucleic acid; EU: European Union; FAO: the U. N. Food and Agriculture Organization; GE: genetically engineered; GM: genetically modified; GMO: genetically modified organism; NGO: non-governmental organization; NOSB: National Organic Standards Board; PRSV: papaya ringspot virus; R-DNA: recombinant DNA; SDN: site-directed nuclease; UK: United Kingdom; USDA: U.S. Department of Agriculture.

\section{Compliance with ethical guidelines}

\section{Competing interests}

The author declares that she has no competing interests. 
Received: 26 March 2015 Accepted: 31 July 2015

Published online: 21 August 2015

\section{References}

1. Lagi M, Bertrand KZ, Bar-Yam Y (2011) The food crises and political instability in North Africa and the Middle East. Available at SSRN 1910031

2. Bittman M (2014) Don't ask how to feed the 9 billion. New York Times, November 11

3. United Nations DoEaSA, Population Division (2013) World population prospects: the 2012 revision. United Nations Food and Agriculture Organization. Report No.: 0470670592

4. Gerland P, Raftery AE, Ševčíková H, Li N, Gu D, Spoorenberg T et al (2014) World population stabilization unlikely this century. Science 346(6206):234-237

5. Ray DK, Mueller ND, West PC, Foley JA (2013) Yield trends are insufficient to double global crop production by 2050. PLoS One 8(6):e66428

6. Ayensu E, van Claasen DR, Collins M, Dearing A, Fresco L, Gadgil M et al (1999) International ecosystem assessment. Science 286(5440):685-686

7. Cardinale BJ, Duffy JE, Gonzalez A, Hooper DU, Perrings C, Venail $P$ et al (2012) Biodiversity loss and its impact on humanity. Nature 486(7401):59-67

8. Diamond J (1987) The worst mistake in the history of the human race. Discover. 8(5):64-66

9. Doebley JF, Gaut BS, Smith BD (2006) The molecular genetics of crop domestication. Cell 127(7):1309-1321. doi:10.1016/j.cell.2006.12.006

10. Harris DR (1996) The origins and spread of agriculture and pastoralism in Eurasia: crops, fields, flocks and herds. University College London Press, London

11. Rimas A, Fraser E (2010) Empires of food: feast, famine, and the rise and fall of civilizations. Simon and Schuster, New York

12. Malthus T (1798) An essay on the principle of population. St. Paul's Church-Yard, London (J. Johnson)

13. Priestly J (2013) Experiments and observations on different kinds of air. Cambridge University Press, Cambridge

14. de Saussure N-T (1804) Recherches chimiques sur la vegetation. Nyon, Paris

15. Bear FE (1938) Theory and practice in the use of fertilizers, 2nd edn. Wiley, New York

16. Russel DA, Williams GG (1977) History of chemical fertilizer development. Soil Sci Soc Am J 41(2):260-265

17. Smil V (2004) Enriching the earth: Fritz Haber, Carl Bosch, and the transformation of world food production. MIT Press, Cambridge

18. Fuller DQ, Allaby R (2009) Seed dispersal and crop domestication: shattering, germination and seasonality in evolution under cultivation. In: Østergaard L (ed) Annual plant reviews, vol 38. Wiley-Blackwell, Oxford, pp 238-295

19. Fedoroff NV (2003) Prehistoric GM corn. Science 302(5648):1158-1159

20. Jaenicke-Despres V, Buckler ES, Smith BD, Gilbert MTP, Cooper A, Doebley $J$ et al (2003) Early allelic selection in maize as revealed by ancient DNA. Science 302(5648):1206-1208

21. Boyer C, Shannon J (1983) The use of endosperm genes for sweet corn improvement. In: Janick J (ed) Plant breeding reviews. Springer, New York, pp 139-161

22. Carlson EA (1966) The gene: a critical history. W. B. Saunders, Philadelphia

23. Crow JF (1998) 90 years ago: the beginning of hybrid maize. Genetics 148(3):923-928

24. Crabb AR (1947) The hybrid-corn makers. Prophets of plenty. Rutgers University Press, New Brunswick

25. Maluszynski M, Ahloowalia BS, Sigurbjörnsson B (1995) Application of in vivo and in vitro mutation techniques for crop improvement. In: Cassells AC, Jones PW (eds) The methodology of plant genetic manipulation: criteria for decision making. Springer, Netherlands, pp 303-315

26. Binswanger H (1986) Agricultural mechanization: a comparative historical perspective. World Bank Res Obs. 1(1):27-56

27. Dimitri C, Effland A, Conklin N (2005) The 20th century transformation of US agriculture and farm policy: USDA, Service UER. Report No.: Economic Information Bulletin No. 3

28. Ehrlich P (1968) The population bomb. Random House, New York
29. Khush GS (2001) Green revolution: the way forward. Nat Rev Genet. 2(10):815-822

30. Fedoroff NV, Brown NM (2004) Mendel in the kitchen: a scientist's view of genetically modified food. Joseph Henry Press, Washington, DC

31. Birch RG (1997) Plant transformation: problems and strategies for practical application. Annu Rev Plant Biol 48(1):297-326

32. Batista R, Saibo N, Lourenço T, Oliveira MM (2008) Microarray analyses reveal that plant mutagenesis may induce more transcriptomic changes than transgene insertion. Proc Natl Acad Sci USA 105(9):3640-3645

33. Wu J, Yu H, Dai H, Mei W, Huang X, Zhu S et al (2012) Metabolite profiles of rice cultivars containing bacterial blight-resistant genes are distinctive from susceptible rice. Acta Biochim Biophys Sinica gms043

34. Shivaprasad PV, Dunn RM, Santos BA, Bassett A, Baulcombe DC (2012) Extraordinary transgressive phenotypes of hybrid tomato are influenced by epigenetics and small silencing RNAs. EMBO J 31(2):257-266

35. Baudo MM, Lyons R, Powers S, Pastori GM, Edwards KJ, Holdsworth MJ et al (2006) Transgenesis has less impact on the transcriptome of wheat grain than conventional breeding. Plant Biotechnol J 4(4):369-380

36. Gao L, Cao Y, Xia Z, Jiang G, Liu G, Zhang W et al (2013) Do transgenesis and marker-assisted backcross breeding produce substantially equivalent plants? A comparative study of transgenic and backcross rice carrying bacterial blight resistant gene Xa21. BMC Genom 14(1):738

37. Richroch AE (2013) Assessment of GE food safety using '-omics' techniques and long-term animal feeding studies. New Biotechnol 30:351-354

38. Hilder VA, Boulter D (1999) Genetic engineering of crop plants for insect resistance-a critical review. Crop Prot. 18(3):177-191

39. Tan S, Evans R, Singh B (2006) Herbicidal inhibitors of amino acid biosynthesis and herbicide-tolerant crops. Amino Acids 30(2):195-204

40. Lee S, Clay D, Clay S (2014) Impact of herbicide tolerant crops on soil health and sustainable agriculture crop production. In: Songstad DD, Hatfield JL, Tomes DT (eds) Convergence of food security, energy security and sustainable agriculture. Biotechnology in Agriculture and Forestry. Springer, New York, pp 211-236

41. Abel PP, Nelson RS, De B, Hoffmann N, Rogers SG, Fraley RT et al (1986) Delay of disease development in transgenic plants that express the tobacco mosaic virus coat protein gene. Science 232(4751):738-743

42. Gonsalves D (1998) Control of papaya ringspot virus in papaya: a case study. Annu Rev Phytopathol 36(1):415-437

43. Tennant P, Fermin G, Fitch M, Manshardt R, Slightom J, Gonsalves D (2001) Papaya ringspot virus resistance of transgenic Rainbow and SunUp is affected by gene dosage, plant development, and coat protein homology. Eur J Plant Pathol 107(6):645-653

44. Podevin N, Davies HV, Hartung F, Nogue F, Casacuberta JM (2013) Sitedirected nucleases: a paradigm shift in predictable, knowledge-based plant breeding. Trends Biotechnol 31(6):375-383

45. James C (2015) Global status of commercialized biotech/GM crops. International Service for the Acquisition of Agri-biotech Applications (ISAAA), Ithaca, New York

46. Klümper W, Qaim M (2014) A meta-analysis of the impacts of genetically modified crops. PLoS One 9(11):e111629

47. Lemaux PG (2009) Genetically engineered plants and foods: a scientist's analysis of the issues (part II). Plant Biol. 60(1):511

48. Sears MK, Hellmich RL, Stanley-Horn DE, Oberhauser KS, Pleasants JM, Mattila HR et al (2001) Impact of Bt corn pollen on monarch butterfly populations: a risk assessment. Proc Natl Acad Sci 98(21):11937-11942

49. Flockhart D, Pichancourt JB, Norris DR, Martin TG (2015) Unravelling the annual cycle in a migratory animal: breeding-season habitat loss drives population declines of monarch butterflies. J Anim Ecol. 84(1):155-165

50. Green JM (2014) Current state of herbicides in herbicide-resistant crops. Pest Manat Sci. 70(9):1351-1357

51. Duke SO (2015) Perspectives on transgenic, herbicide-resistant crops in the USA almost 20 years after introduction. Pest Manag Sci 71(5):652-657

52. Lemaux PG (2008) Genetically engineered plants and foods: a scientist's analysis of the issues (part I). Annu Rev Plant Biol 59(1):771

53. Munkvold GP (2003) Cultural and genetic approaches to managing mycotoxins in maize. Annu Rev Phytopathol 41(1):99-116

54. Hutchison W, Burkness E, Mitchell P, Moon R, Leslie T, Fleischer SJ et al (2010) Areawide suppression of European corn borer with Bt maize reaps savings to non-Bt maize growers. Science 330(6001):222-225 
55. Wu S-H, Ho C-T, Nah S-L, Chau C-F (2014) Global hunger: a challenge to agricultural, food, and nutritional sciences. Crit Rev Food Sci Nutr 54(2):151-162

56. Cohen JE (2003) Human population: the next half century. Science 302(5648):1172-1175

57. DESA (2013) World population prospects: the 2012 revision. Department of Economic and Social Affairs, United Nations

58. AG LCAM (2009) The land commodities global agriculture and farmland investment report 2009

59. Giordano M, Villholth KG (2007) The agricultural groundwater revolution: opportunities and threats to development. CABI, Oxfordshire

60. IWMI (2007) Does food trade save water? Water policy briefing. International Water Management Institute, Colombo, Sri Lanka

61. Graff G, Hochman G, Zilberman D (2013) The research, development, commercialization, and adoption of drought and stress-tolerant crops. In: Tuteja N, Gill SS (eds) Crop improvement under adverse conditions. Springer, New York, pp 1-33

62. FAO (2009) How to feed the World in 2050. UN Food and Agriculture Organization, Rome

63. Odegard I, van der Voet E (2014) The future of food - scenarios and the effect on natural resource use in agriculture in 2050. Ecol Econ 97:51-59

64. IPCC (2014) Summary for policymakers

65. Challinor A, Watson J, Lobell D, Howden S, Smith D, Chhetri N (2014) A meta-analysis of crop yield under climate change and adaptation. Nat Clim Change. 4(4):287-291

66. Tilman D, Balzer C, Hill J, Befort BL (2011) Global food demand and the sustainable intensification of agriculture. Proc Natl Acad Sci USA 108(50):20260-20264

67. Kershen DL (2013) The contested vision for agriculture's future: sustainable intensive agriculture and agroecology. Creighton Law Rev 46(4):591-618

68. Grassini P, Eskridge KM, Cassman KG (2013) Distinguishing between yield advances and yield plateaus in historical crop production trends. Nat Commun 4:2918. doi:10.1038/ncomms3918

69. OSTP (1986) Coordinated framework for regulation of biotechnology. Federal Register 51:23302-23350

70. McDougall P (2011) The cost and time involved in the discovery, development and authorisation of a new plant biotechnology derived trait. Crop Life International

71. Graff GD, Zilberman D, Bennett AB (2009) The contraction of agbiotech product quality innovation. Nat Biotechnol 27(8):702-704

72. Kershen DL (2014) European decisions about the "Whack-a-mole" game. GM Crops Food. 5(1):4-7

73. Abrahams D (2014) Legal considerations related to the authorization, import and cultivation of GM crops in the European Union: a precedent for other regulated industries? BioSciences Law Rev. 13:155-160

74. Smyth SJ, Phillips PW (2014) Risk, regulation and biotechnology: the case of GM crops. GM Crops Food 5(3):170-177

75. Paarlberg R (2009) Starved for science: how biotechnology is being kept out of Africa. Harvard University Press

76. Alberts B, Beachy R, Baulcombe D, Blobel G, Datta S, Fedoroff N et al (2013) Standing up for GMOs. Science 341(6152):1320

77. Mayo-Wilson E, Imdad A, Herzer K, Yakoob MY, Bhutta ZA (2011) Vitamin A supplements for preventing mortality, illness, and blindness in children aged under 5: systematic review and meta-analysis. BMJ 343:d5094

78. Tanumihardjo SA (2011) Vitamin A: biomarkers of nutrition for development. Am J Clin Nutrition 94(2):658S-665S
79. Paine JA, Shipton CA, Chaggar S, Howells RM, Kennedy MJ, Vernon G et al (2005) Improving the nutritional value of Golden Rice through increased pro-vitamin A content. Nature Biotechnol 23:482-487

80. Potrykus I (2010) Regulation must be revolutionized. Nature 466(7306):561

81. Wesseler J, Zilberman D (2014) The economic power of the golden rice opposition. Env Dev Econ. 19(06):724-742 (Quote: “'So, if introduced on a large scale, golden rice can exacerbate malnutrition and ultimately undermine food security.' This statement by Greenpeace (2012: 3 ) is in strong contradiction to the reported impacts of vitamin A deficiency and the nutritional impacts of vitamin A enriched diets. More than 125 million children under five years of age suffer from vitamin A deficiency (VAD). Dietary VAD causes 250,000-500,000 children to go blind each year.")

82. Paarlberg R (2014) Consequences of the anti-GMO campaigns. Bread and Brain, Education and Poverty; 4-6 November 2013; Vatican; Pontifical Acad Sci

83. House of Commons | Science and Technology Committee (2015). Advanced genetic techniques for crop improvement: regulation. The Stationery Office, London 2015, p 69. (http://www.publications.parliament. uk/pa/cm201415/cmselect/cmsctech/328/32809.htm\#a28)

84. Apel A (2010) The costly benefits of opposing agricultural biotechnology. New Biotechnol 27:635-640 (Quote: “The key players encompassed by the definition of 'opponent' of engineered crops reap billions annually from restricting agricultural biotechnology or the food that results. Indeed, more money can be made from restricting agricultural biotechnology than by delivering it.)

85. Co-Founder of Greenpeace: Greenpeace is Wrong about Golden Rice. http://www.science20.com/science_20/cofounder_of_greenpeace_ greenpeace_is_wrong_about_golden_rice-122754. (Quotes: "Greenpeace is clearly a big-money operation these days, as intent as feeding itself as any corporation is. They need new causes to keep fundraising humming along - and that has to be the reason they oppose Golden Rice. Because Greenpeace is humanitarian and opposing Greenpeace is the least humanitarian thing imaginable. While Golden Rice has been opposed by Greenpeace and others as "Frankenfood", the World Health Organization notes that 18 million children have died due to vitamin A deficiency and another 18 million have gone blind - all entirely preventable, while still feeding them.")

86. Chassy B, Tribe D, Brookes G, Kershen D (2014) Organic marketing report. Academics review. http://academicsreview.org/wp-content/ uploads/2014/04/Academics-Review_Organic-Marketing-Report.pdf

87. Carson R (1962) Silent spring. Houghton Mifflin, Boston

\section{Submit your next manuscript to BioMed Central and take full advantage of:}

- Convenient online submission

- Thorough peer review

- No space constraints or color figure charges

- Immediate publication on acceptance

- Inclusion in PubMed, CAS, Scopus and Google Scholar

- Research which is freely available for redistribution

Submit your manuscript at

www.biomedcentral.com/submit
C Biomed Central 